\title{
Techno-Economic Optimization of Solar/Wind Turbine System for Remote Mosque in Saudi Arabia Highway: Case Study
}

\author{
Hazim Moria \\ Department of Mechanical Engineering Technology \\ Yanbu Industrial College \\ Yanbu Al-Sinaiyah City 41912, Kingdom of Saudi Arabia
}

\begin{abstract}
This paper presents a study of optimizing hybrid power system for a remote traveler's mosque on the highway of the western coastal region at Alrais town, Saudi Arabia. Typical energy consumption profiles were estimated based on a medium-sized mosque over the four seasons as per energy requirements. The HOMER Pro software is used as a tool to size and optimize the optimal system. The optimal finding shows that hybrid solar with wind turbine achieved the lowest net present cost (NPC) and cost of energy (COE) due to the high potential of solar radiation and wind speed. The proposed configuration system can contribute in a wide renewable energy application in Saudi Arabia especially in remote region. A comprehensive analytical, descriptive, and modeling of the configurations also presented here.
\end{abstract}

Keywords - Saudi Arabia; Solar energy; wind energy; hybrid $P V$ wind system; techno-economic analysis.

\section{INTRODUCTION}

The world began investing heavily in renewable energy resources. This trend has been driven by continuous climate change that has led to global warming [1-4]. The increased exploitation aims at reducing carbon emissions from energy generation and enhancing energy security/reliability [5]. Population growth has a direct effect on energy needs. Saudi Arabia's growth plan demonstrates that in the future, increasing power will be needed, thereby increasing power generation capacity. The increased consumption of fossil fuel has forced the Kingdom of Saudi Arabia to concentrate more on renewable energy generation. The Kingdom is aware that decreasing dependence on fossil fuels will have a positive impact on economic growth and environmental issues in the country. The generation of electricity from renewable energy resources instead of fossil fuels will increase the Kingdom's petroleum revenue. Also, $\mathrm{CO}_{2}$ emissions from fossil-fuel energy systems are predicted to increase by around $20 \%$ of current global energy-related $\mathrm{CO}_{2}$ emissions by 2030 [6].

Solar and wind energy in Saudi Arabia's are the largest source of renewable energy due to the strategic geographic location in the so-called sunbelt and clear skies over the year [7]. The average sunlight power is $2,200 \mathrm{kWh} / \mathrm{m}^{2}$ [8], and therefore, it is worth to generate power from the sun in different technology. Photovoltaics is semiconductor devices able to convert the solar sunlight into electricity. It is clean energy, low maintenance and worthy candidate for generating power $[9,10]$. Therefore, utilize the solar energy in several applications such houses, mosques, and telecommunication towers. The wind energy takes second place in Saudi Arabia as a source of renewable energy [11]. The viable wind velocity potential and the solar radiation is around $5.7 \mathrm{~m} / \mathrm{s}$ and $2200 \mathrm{kWh} / \mathrm{m}^{2}$ respectively [8, 12-15]. Saudi Arabia has relatively large solar and wind energy that can be harvested, especially in coastal areas. Wind and solar are intermittent resources and depend on conditions of climate and geography. Wind/solar electricity hybridizations are usually more reliable and cheaper than standalone wind or solar power systems [1619]. The time of day, the year and the type of terrain also vary with renewable energy such as wind or solar, which all influence electricity production and energy consumption [20,21]. Rehman et al. (2003) have present a cost calculation methodology at twenty locations across the Kingdom of Saudi Arabia for each $\mathrm{kWh}$ of electricity produced using long-term mean wind speed data. The results of this study indicated that, lowest cost (US\$ 0.0234 per $\mathrm{kWh}$ ) for the power generation in Yanbu, while Qaisumah city was one of the best sites, costing US\$ 0.0256 per $\mathrm{kWh}$ for power generation. The potential of the hybrid wind and solar energy in Saudi Arabia's west coast area was investigated by Ramli et al. (2015). The results show that wind and solar energy is adequate to provide electricity in the western coastal zone of Saudi Arabia. The wind turbine generates lower power than the same size and site PV array.

Muslims gather in the mosque for their daily congregation, weekly speeches, annual events, and other religious and social activities. Mosques vary considerably in size: from small to 50,150 people to large and tens of thousands of worshippers. Elshurafa et al. (2019) have carried out a technological, economic analysis of an installed solar photovoltaic system on the rooftop of the mosque. The analysis showed that the annual mosque bill could be reduced to almost zero under a net metering mechanism. Further research designed a hybrid micro-grid system for a remote mosque in Libya state by Mustafa et al. (2014). The authors proposed the incorporation of a PV system to reduce dependence on diesel. A gridconnected mosque will have different dynamics and constraints than an off-grid one. Furthermore, a study on a specific mosque in Malaysia showed that the installation of a PV system would reduce the energy bill by $47 \%$ [25]. The objective of this study is to investigate the economic analysis of using hybrid solar and wind system to generate electric power for remote mosque on western coastal highway named Alrais town $23^{\circ} 58^{\prime} \mathrm{N}, 38^{\circ} 64^{\prime} \mathrm{E}$. The investigation was performed using HOMER Pro software based on Net Price Cost (NPC), Cost of Energy (COE) and operation cost. This 
study will contribute widely to the development of Saudi Arabia's renewable energy system.

\section{SITE STUDY}

The proposed project is travelers' mosque in Alrais allocated on the western coastal highway $50 \mathrm{Km}$ from Yanbu towards Jeddah, Saudi Arabia. The latitude and longitude of the allocated mosque are $23^{\circ} 58^{\prime} \mathrm{N}, 38^{\circ} 64^{\prime} \mathrm{E}$, respectively (Figure 1). The summer climate is long, sweltering, muggy and dry; the winters are short, comfortable, dry and windy; and the weather is mostly clear throughout the year. The temperature typically ranges between $15{ }^{\circ} \mathrm{C}$ and $39{ }^{\circ} \mathrm{C}$ throughout the year and is rarely less than $11^{\circ} \mathrm{C}$ or above 43 ${ }^{\circ} \mathrm{C}$. The hot season lasts 4.9 months, with an average daily high temperature above $36^{\circ} \mathrm{C}$, from May 15 to October 10 . August 22, with an average high of $43^{\circ} \mathrm{C}$ and a low of $27^{\circ} \mathrm{C}$, is the hottest day of the year. The cold season lasts 2.8 months, with an average daily high temperature below $29^{\circ} \mathrm{C}$, from December 11 to March 4. January 21 is the coldest day of the year, with an average $15{ }^{\circ} \mathrm{C}$ low and $27{ }^{\circ} \mathrm{C}$ high. The importance of the proposed location is considered to have more payers due passing the Meqqat to Makkah and high number of people who are working at industries in Yanbu. Hence, extending the grid to this site is not an economical choice, as the energy required is minimal, which increases the $\mathrm{Kw} / \mathrm{h}$ cost. As an alternative, this study will investigate the available hybrid off-grid renewable energy.

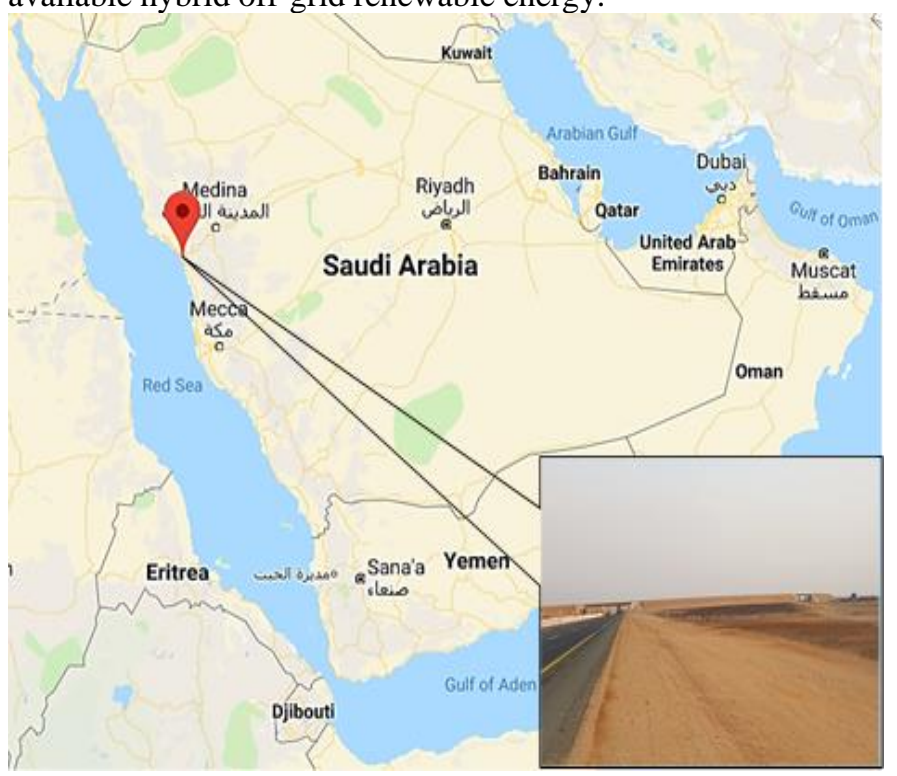

Fig. 1. Site location of the proposed mosque

\section{METHODOLOGY}

HOMER Pro is a software developed by the Laboratory of US National Renewable Energy. It is used for designing and evaluating the configurations for on-grid and off-grid power systems for remote, standalone, and distributed generating forms technically and financially. It is also a model of optimization that simulates and sorts of varied configurations of energy sources systems based on NPC. The software, however, evaluates the technical feasibility of the energy source system whether it can fulfill electric and thermal loads and other limitations of the user. Also, it evaluates the system's NPC, which is the cost of the installation and operation of the system for the entire system lifetime.
HOMER Pro model all system configurations by simulating its process for an hourly period of one year. HOMER Pro designs each system configuration by simulating its operation for one year in an hourly time step. The renewable energy available is calculated and compared to the required electricity, where the energy supply system is estimated to satisfy demand. Any excess electricity then expanded to other secondary requirements. Although the 1-hour time step by HOMER Pro is small enough to record the largest statistical variability in load and fluctuating renewable resources, the calculation does not become excessively slow. Following oneyear calculation, any system restrictions imposed by a user will be evaluated; for example, the fraction of the total electrical demand served or the share of energy generated from renewable sources.

\section{HYBRID SYSTEM COMPONENTS MODELLING}

\section{A. Components Considered}

Hybrid power system enables various combinations. This benefits in setting up a system based on the available energy resources, costs, and load requirements at any site. A combination of PV, wind turbine, battery and converter (DC to AC) included in this study to meet the mosque load requirements. The hybrid power optimization tool was used in this study to simulate the hybrid system's best size and to meet the specific city demand based on the present minimum net cost. Figure 2 shows the schemas configuration of the hybrid system in this study. The software assumes when calculating the present value of the components that all costs rise at the same rate over the lifetime as the real interest rate rather than the nominal interest rate. This study considers discount rate, inflation rate and annual capacity shortage of $8 \%, 2 \%$, and $0 \%$ during the project lifetime as 25 years.

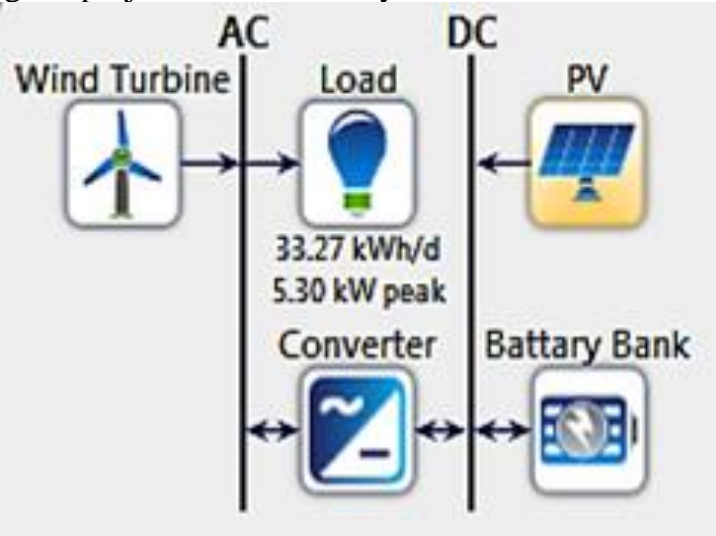

Fig. 2. Schemas configuration of a hybrid system using HOMER Pro

\section{B. Loads Demand}

The proposed mosque is a simple walled, rectangular wall with a roofed hall of prayer. The rectangle's long side is oriented towards the holy mosque in the city of Makah "kiblah". On a daily and hourly basis, a $20 \%$ safety factor has been added to the calculated load estimated to randomize the load profile and make it more realistic. Table 1 shows the number of equipment and electrical loads for the proposed mosque. 


\begin{tabular}{|l|c|c|c|} 
TABLE I. NUMBER OF EQUIPMENT AND ELECTRICAL LOAD \\
\begin{tabular}{|l|c|c|c|}
\hline \multicolumn{1}{|c|}{ Load Type } & No. of Unit & $\begin{array}{c}\text { Max } \\
\text { Power, } \mathbf{~ k W}\end{array}$ & $\begin{array}{c}\text { Total Power, } \\
\mathbf{k W}\end{array}$ \\
\hline Fan & 10 & 0.075 & 0.75 \\
\hline Air Condition & 5 & 0.75 & 3.75 \\
\hline Water Pump & 1 & 0.55 & 0.55 \\
\hline External lighting & 16 & 0.02 & 0.40 \\
\hline Internal lighting & 20 & 0.02 & 0.40 \\
\hline Audio Sound System & 1 & 0.4 & 0.40 \\
\hline \multicolumn{4}{|c|}{ Total } \\
\hline
\end{tabular}
\end{tabular}

As shown in Figure 3, the load profile found in this investigation was based on a typical intermittent operation of the mosque use during the daily five prayers "based on UmmAlqura prayer calendar" and the weather conditions. The average energy consumption and the peak load over the year is $33.27 \mathrm{kWh} /$ day and $5.3 \mathrm{~kW}$ respectively. The peak month in August was observed due to high energy consumption by air conditioning and fan. The average maximum and minimum load are assumed to be recorded in August and January as 51.99 and $12.61 \mathrm{kWh} /$ day. It is also found that at 17:00, the highest consumption while the lowest was recorded from 8:00 to 10:00 due to no activities. The annual load factor is 0.26 .

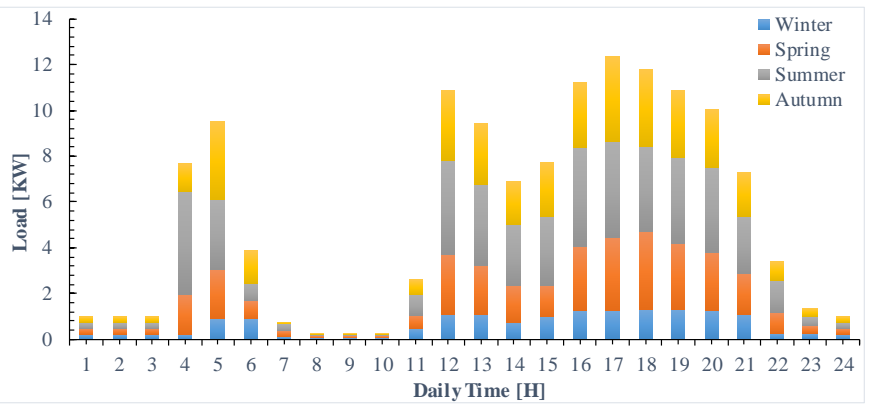

Fig. 3. Load needs over the year in four seasons

\section{Renewable Resources}

Solar insolation and wind speed data were acquired from solar energy database and NASA surface meteorology. HOMER Pro can use Graham algorithm, latitude, and monthly average values to synthesize hourly solar radiation data for any location over the year. The data generated in this manner will not replicate the area's solar radiation data characteristics perfectly. The average clearness index is 0.683 , and the average annual solar insolation in Alrais town is $6.28 \mathrm{kWh}$ $/ \mathrm{m} 2 /$ day. Hence, in the summer months, solar radiation is higher than in other months, and thus higher energy output is expected. Figure 4 illustrates the average annual solar radiation and cleanness index in this area.

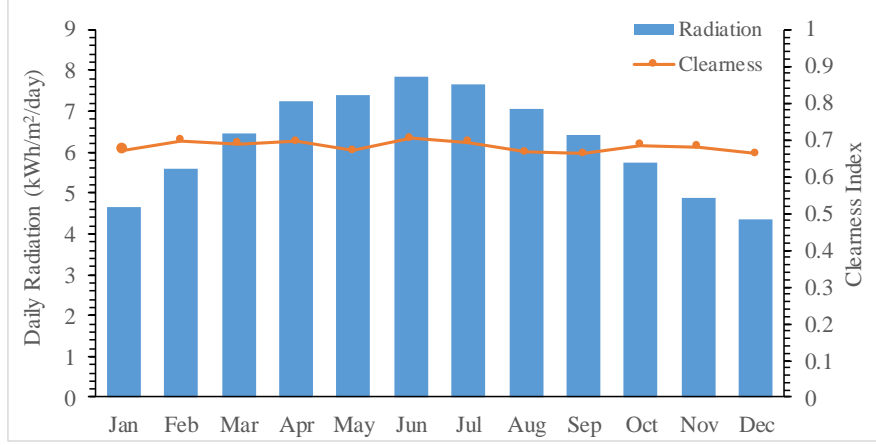

Fig. 4. Monthly solar radiation profile and clearness index at Alrais town

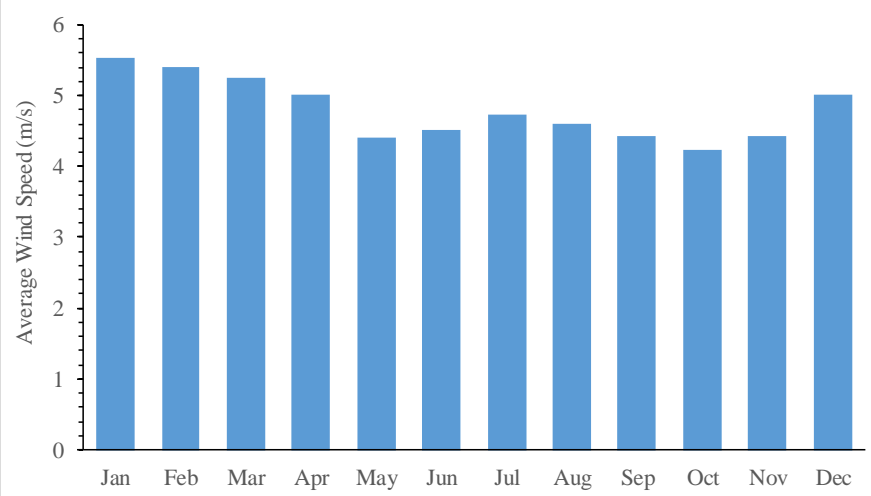

Fig. 5. Monthly average wind speeds variation over the year at Alrais town

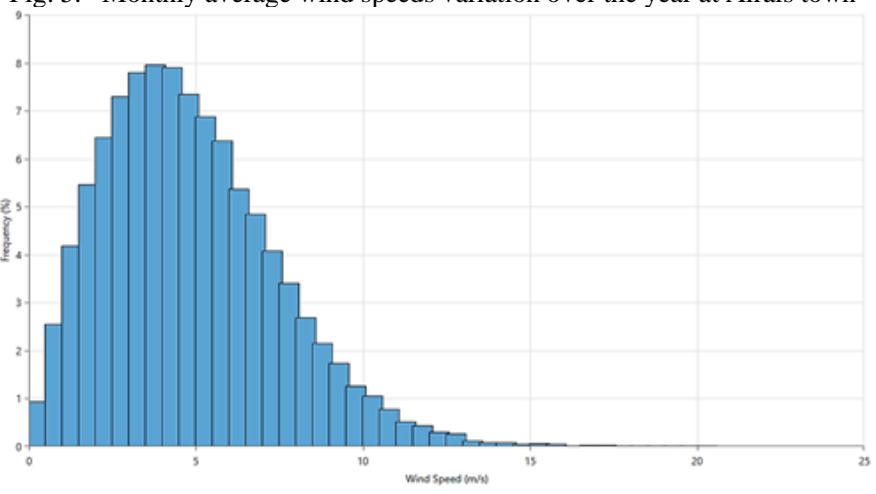

Fig. 6. Density as a function of wind speeds at Alrais town

\section{Solar Photovoltaic}

The Photovoltaic panels were selected according to high reliable performance in temperature, humidity, extreme desert, and coastal environments. The details of the technical and economic parameters of the selected PV are shown in Table 2. The Solar decline as the angle from the equator to the center of the Sun varies between $+23.45^{\circ}$ and $-23.45^{\circ}[26,27]$.

TABLE II. PV TECHNICAL AND ECONOMIC PARAMETERS
\begin{tabular}{|l|c|}
\hline \multicolumn{1}{|c|}{ Parameter } & Value and Unit \\
\hline Cell Type & $\begin{array}{c}\text { Thin-film CdTe } \\
\text { semiconductor, up to } 216 \text { cells }\end{array}$ \\
\hline Model Size & $117.5 \mathrm{~W}$ \\
\hline Efficiency & $16.32 \%$ \\
\hline Derating Factor & $90 \%$ \\
\hline Lifetime & 25 Years \\
\hline Temperature Effect Power & $-0.28 \%$ per ${ }^{\circ} \mathrm{C}$ \\
\hline Voltage at $P_{\max }$ & $71.2 \mathrm{~V}$ \\
\hline Current at $P_{\max }$ & $1.65 \mathrm{~A}$ \\
\hline Length $\times$ Width $\times$ Thickness & $1200 \times 600 \times 6.8 \mathrm{~mm}$ \\
\hline Initial Capital Cost & $1500 \$ / \mathrm{kW}$ \\
\hline Replacement Cost & $1000 \$ / \mathrm{kW}$ \\
\hline Operation and Maintenance Cost & $10 / \mathrm{kW} / \mathrm{year}$ \\
\hline Tracking System & No \\
\hline
\end{tabular}

\section{E. Wind Turbine}

The wind turbine was selected according to lowest start-up speed, high efficiency and extreme desert and coastal environments. The details of technical parameters and economic assumptions of the selected wind turbine are shown in Table 3. 
TABLE III. WIND TURBINE TECHNICAL AND ECONOMIC

\begin{tabular}{|c|c|}
\hline \multicolumn{2}{|c|}{ PARAMETERS } \\
\hline Parameter & Value and Uni \\
\hline Rated Output & $5.1 \mathrm{~kW}$ \\
\hline Speed Cut in & $2.7 \mathrm{~m} / \mathrm{s} / 6 \mathrm{mph}$ \\
\hline Number of Blades & 3 \\
\hline Voltage & $48 \mathrm{~V}$ \\
\hline Lifetime & 20 Years \\
\hline Initial Capital Cost & $5000 \$$ \\
\hline Replacement Cost & $4500 \$$ \\
\hline Operation and Maintenance Cost & 20 \$/year \\
\hline
\end{tabular}

\section{F. Battery Storage}

To fulfill continuous operation, even in the hottest and hardest operating environment, the selected kinetic Battery (EnerSy) delivers exceptional cycle performance in both floating and fast-charging applications. The details of technical and economic parameters of the selected battery are given in Table 4. In this study, the sizing was investigated using HOMER Pro optimizer.

TABLE IV. BATTERY TECHNICAL AND ECONOMIC

\begin{tabular}{|l|c|}
\multicolumn{2}{c}{ PArameter } \\
\hline Model Type & Thin plate pure lead \\
\hline Capital Cost & $800 \$ /$ battery \\
\hline Replacement Cost & $800 \$ /$ battery \\
\hline Operation and Maintenance Cost & $10 \$ /$ battery/year \\
\hline Nominal Voltage & $12 \mathrm{~V}$ \\
\hline Nominal Capacity & $9.16 \mathrm{kWh}$ \\
\hline Maximum Capacity & $763 \mathrm{Ah}$ \\
\hline Roundtrip Efficiency & $97 \%$ \\
\hline Minimum Battery Life & 15 Years \\
\hline
\end{tabular}

\section{G. Convertor}

HOMER Pro simulated the power switched between the inverter and generator for every system that operated parallel. The power comes from both the generator and the batteries at the same time. Further details of technical and economic parameters of the selected battery are shown in Table 5.

TABLE V. CONVERTOR TECHNICAL AND ECONOMIC PARAMETERS

\begin{tabular}{|l|c|}
\hline \multicolumn{1}{|c|}{ Parameter } & Value and Unit \\
\hline Capital Cost & $300 \$ /$ battery \\
\hline Replacement Cost & $300 \$ /$ battery \\
\hline Operation and Maintenance Cost & 0 \$/battery/year \\
\hline Inverter Efficiency & $95 \%$ \\
\hline Inverter Lifetime & 15 Years \\
\hline Rectifier Relative Capacity & $100 \%$ \\
\hline Rectifier Efficiency & $95 \%$ \\
\hline
\end{tabular}

\section{OPTIMAZIATION RESULTS}

The key parameters for this study that are used to evaluate the techno-economic optimization of the selected remote mosque allocated in the central of western coastal region are: NPC, COE, and monthly average electricity production. NPC and LCOE and computes as illustrated in Eq. (1) and (3).

$$
N P C=\frac{C_{a n n, t o}}{\operatorname{CRF}(i, N)}
$$

$\operatorname{LCOE}\left(\frac{\$}{k W h}\right)=\frac{C_{a n n, t o}}{R_{\text {prim }}+R_{\text {def }}+R_{\text {tot }, \text { grid }, \text { sales }}}$

Where,

$\mathrm{R}_{\text {prim }}=$ Primary load, $\mathrm{kWh} / \mathrm{yr}$;

$\mathrm{R}_{\text {def }}=$ Deferrable load, $\mathrm{kWh} / \mathrm{yr}$;

$\mathrm{R}_{\text {tot,grid sales }}=$ Total grid sales, $\mathrm{kWh} / \mathrm{yr}$

The optimal configuration has the minimum values of renewable resources as shown in Figure 7 compare to other configurations. It involves hybrid of PV/wind turbine/battery and converter. The optimal configuration is consisting of 10 $\mathrm{kW}$ panel photovoltaic, $6 \mathrm{~kW}$ MPPT, one wind turbine and 8 batteries. The system can generate all loads required based on solar and wind resources as shown in Figure 8.

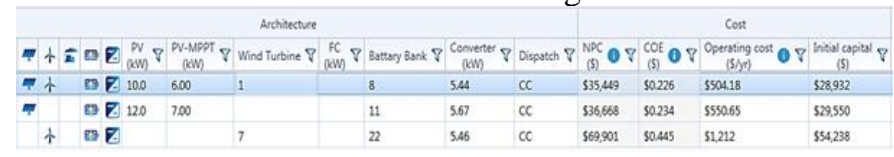

Fig. 7. Screenshot of HOMER Pro Optimization Results

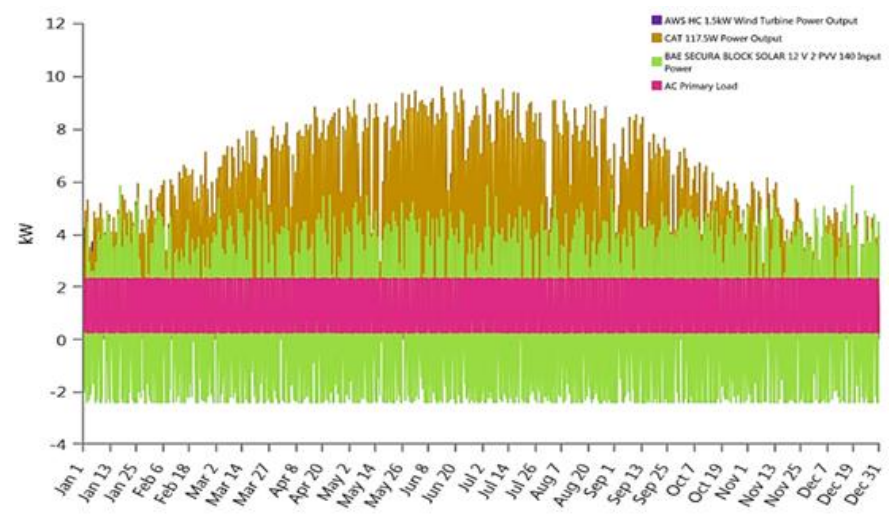

Fig. 8. System time series

\section{A. Economic Analysis}

Figure 9 demonstrated the net present cost by component for the optimum configuration in \$ included battery bank, PV, PV dedicated converter, system converter, and wind turbine. The findings revealed that most feasible economically obtained with a minimum total NPC of $35449.35 \$$ and minimum COE of $0.226 \$ / \mathrm{kWh}$, although the system represents a higher initial capital of $28932 \$$ and $100 \%$ of renewable fraction. The operating cost is estimated to be 504.18 \$/year. The cost summary in \$ included capital, operation, and maintenance, replacement, salvage and resources for the system can be found in Figure 10.

Where,

$\mathrm{C}_{\mathrm{ann}, \mathrm{to}}=$ Total annualized cost, $\$$;

$\mathrm{CRF}(\mathrm{i}, \mathrm{N})=$ Capacity recovery factor;

$\mathrm{i}=$ discount rate;

$\mathrm{N}=$ project lifetime. 


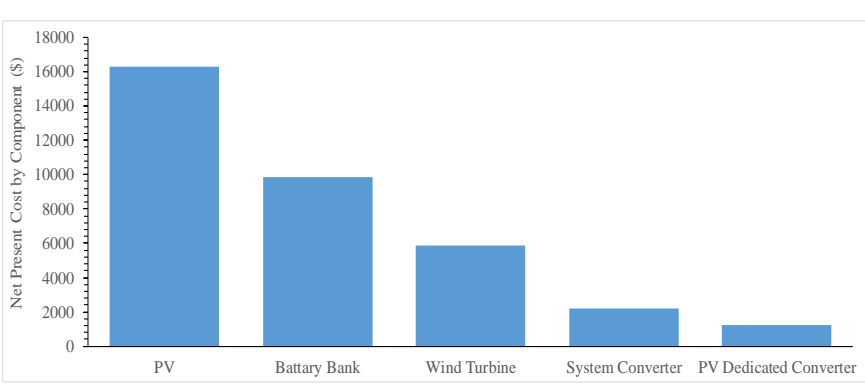

Fig. 9. Net present cost of different component for optimum configuration

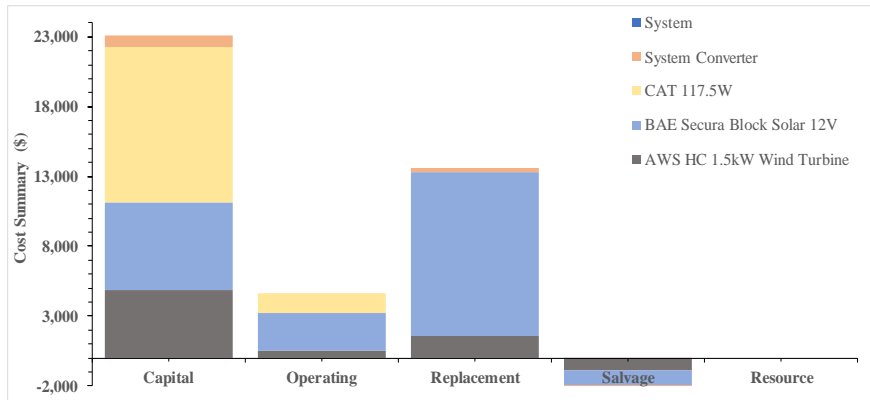

Fig. 10. Cost summary of different component for optimum configuration

\section{B. Electricity Production}

Figure 11 illustrates the distribution of monthly average electricity produced in $\mathrm{MW} / \mathrm{h}$ by the solar $\mathrm{PV}$ and wind turbine. The uses of PV and wind turbine are $71.7 \%$ and $28.3 \%$ respectively. Hence, according to obtained results, solar energy is more economical than electrical energy and has also more potential. The battery state of charge over the year as a function of days and months are shown in Figure 12.

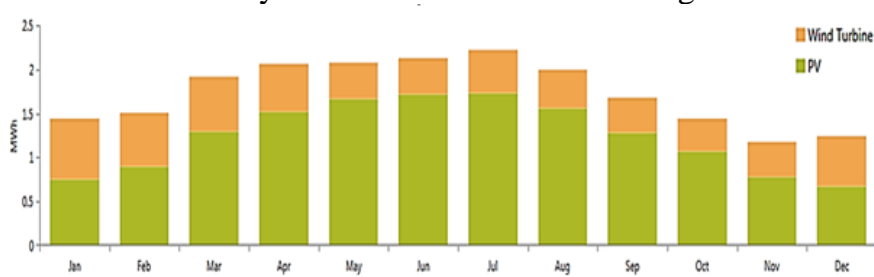

Fig. 11. PV and wind turbine monthly average electricity production

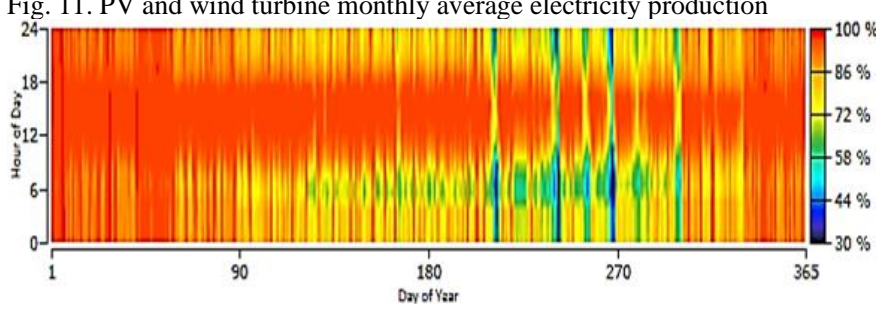

Fig. 12. Battery state of charge from PV and wind turbine over the year

The PV system produces output energy only during the sunset. As displayed in Figure 13, the approximate peak sunshine during the summer period is between 6:00 to 18:00 while in winter is to from 8:00 to 17:00. The high air temperature has an impact on the generated power from PV since it reduces the PV panels efficiency. The pattern of wind turbine power output is illustrated in Figure 14.

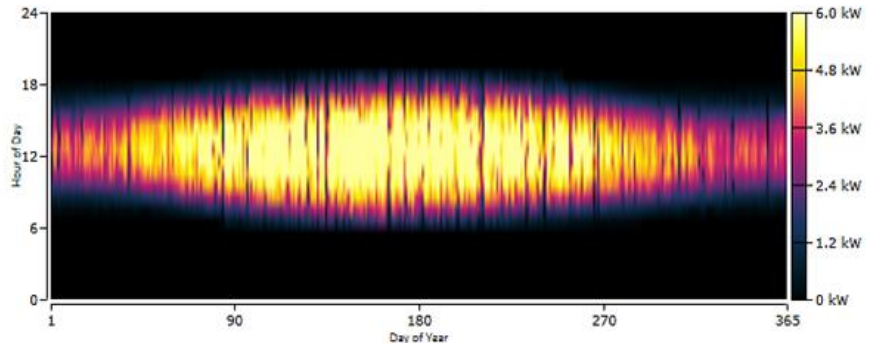

Fig. 13. PV power output pattern

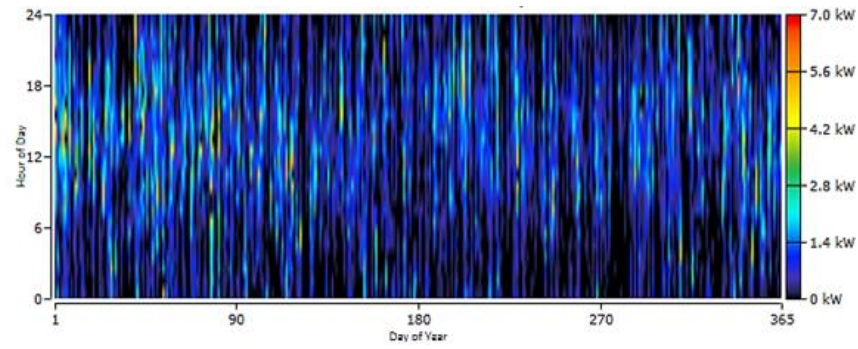

Fig. 14. Wind turbine power output pattern

\section{Comparative Analysis}

The detailed comparative analysis of the obtained simulated configurations using renewable power systems and the rating of all the components considered for the analysis are given in Table 5.

\section{CONCLUSIONS}

Solar and wind energy are an attractive alternative, ample, reliable and clean resource for sustainable development based on the Kingdom and its current energy status and plan. Due to the insufficient and proper mosques and rests on the high ways in Saudi Arabia, this study has investigated the adoption of solar and wind hybrid system. It can be seen from the load profiles that the loads in the summer, autumn and second half of spring are higher than winter due using the air conditioning. Excess electricity can be used in winter and autumn in other applications or sold to the power grid in future in order to reduce energy costs. However, the simulation results revealed that all the renewable resources in each remote mosque configuration promoted energy efficiency and alternatives to fossil fuels and eliminate the emission of greenhouse gases. Results indicate that the most economical and environmental power supply could be generated for the mosque by installing a hybrid of photovoltaic, $6 \mathrm{~kW}$ MPPT, wind turbine, eight battery units, and $5.44 \mathrm{~kW}$ converters. The NPC from the optimum configuration was found $35449.35 \$$ and minimum COE of $0.226 \$ / \mathrm{kWh}$, although the system represents a higher initial capital of $28932 \$$ and $100 \%$ of renewable fraction. The operating cost is estimated to be 504.18 \$/year. The result for the cases when the PV or wind turbine operated separately with the same solar and wind resources, the NPC, COE, and MOC has been found higher and not utilizing the renewable resources compared to the optimum case.

\section{ACKNOWLEDGMENT}

The author owes heartfelt thanks to Professor Dato' Dr. Kamaruzzman bin Sopain, Dr. Ahmed Abdulmula, Dr. Asmaa Soheil Najm for their knowledge, advice and technical assistance in this study. 
TABLE VI. COMPARATIVE ANALYSIS OF VARIOUS CONFIGURATIONS OF RENEWABLE SYSTEMS

\begin{tabular}{|c|c|c|c|c|c|c|c|}
\hline SN & Description & \multicolumn{2}{|c|}{ PV/Wind Turbine/ Battery/Converter } & \multicolumn{2}{|c|}{ PV/Battery/Converter } & \multicolumn{2}{|c|}{ Wind Turbine/ Battery/Converter } \\
\hline \multirow{6}{*}{1} & Architecture & & & & & & \\
\hline & $\mathrm{PV}(\mathrm{kW})$ & \multicolumn{2}{|c|}{10} & \multicolumn{2}{|c|}{12} & \multicolumn{2}{|c|}{0} \\
\hline & MPPT $(\mathrm{kW})$ & \multirow{2}{*}{\multicolumn{2}{|c|}{6}} & \multicolumn{2}{|c|}{7} & \multicolumn{2}{|c|}{0} \\
\hline & No. of Wind Turbine & & & \multicolumn{2}{|c|}{0} & \multicolumn{2}{|c|}{7} \\
\hline & No. of Battery & \multicolumn{2}{|c|}{$\frac{1}{8}$} & \multirow{2}{*}{\multicolumn{2}{|c|}{$\frac{11}{5.67}$}} & \multicolumn{2}{|c|}{22} \\
\hline & Converter $(\mathrm{kW})$ & \multicolumn{2}{|c|}{5.44} & & & & \\
\hline \multirow{7}{*}{2} & Emission (kg/Year) & & & & & & \\
\hline & Carbon dioxide & \multicolumn{2}{|c|}{0} & \multicolumn{2}{|c|}{0} & \multicolumn{2}{|c|}{0} \\
\hline & Carbon monoxide & \multirow{2}{*}{\multicolumn{2}{|c|}{0}} & \multirow{2}{*}{\multicolumn{2}{|c|}{0}} & & \\
\hline & Unburned hydrocarbon & & & & & & \\
\hline & Particulate matter & & & & & & \\
\hline & Sulphur dioxide & & & & & & \\
\hline & $\begin{array}{l}\text { Nitrogen oxides } \\
\end{array}$ & & & & & & \\
\hline & Production (kWh/year) & kWh/yeat & $\%$ & kWh/year & $\%$ & kWh/year & $\%$ \\
\hline & $\mathrm{PV}$ & 14966 & 71.7 & 17816 & 100 & 0 & 0 \\
\hline & Wind turbine & 5913 & 28.3 & 0 & 0 & 41391 & 100 \\
\hline & AC Primary Load & 12143 & 100 & 12138 & 100 & 12140 & 100 \\
\hline & DC Primary Load & 0 & 0 & 0 & 0 & 0 & 0 \\
\hline 3 & Deferrable Load & 0 & 0 & 0 & 0 & 0 & 0 \\
\hline & Excess electricity & 8086 & 38.7 & 4824 & 27.1 & 28720 & 69.4 \\
\hline & Unmet load kW h/yea & 0.745 & 0.00610 & 5.23 & 0.0431 & 3.21 & 0.0265 \\
\hline & Capacity shortage & 11.7 & 0.0961 & 11.9 & 0.0976 & 11.9 & 0.0979 \\
\hline & Renewable Fraction $\%$ & & & & & & \\
\hline & Max. Renew. Penetration \% & & & & & & \\
\hline & Cost $(\$)$ & & & & & & \\
\hline 4 & Total net present cost & & & 366 & & & \\
\hline 4 & Levelized cost of energy & & & & & & \\
\hline & Operating cost & & & & & & \\
\hline & System Converter & Inverter & Rectifier & Inverter & Rectifier & Inverter & Rectifier \\
\hline & Capacity (kW) & 5.44 & 5.44 & 5.67 & 5.67 & 5.46 & 5.46 \\
\hline & Mean output $(\mathrm{kW})$ & 0.975 & 0.0827 & 1.39 & 0 & 0.426 & 0.463 \\
\hline & Minimum output $(\mathrm{kW})$ & 0 & 0 & 0.0750 & 0 & 0 & 0 \\
\hline & Maximum output $(\mathrm{kW})$ & 5.30 & 4.83 & 5.30 & 0 & 5.30 & 5.46 \\
\hline 3 & Capacity factor (\%) & $17.9 \%$ & $1.52 \%$ & 24.5 & 0 & 7.81 & 8.47 \\
\hline & Hours of operation (hrs/year) & 5887 & 1816 & 8760 & 0 & 2957 & 5788 \\
\hline & Energy out (kWh/year) & 8537 & 725 & 12138 & 0 & 3735 & 4053 \\
\hline & Energy in (kWh/year) & 8987 & 763 & 12777 & 0 & 3932 & 4266 \\
\hline & Losses (kWh/year) & 449 & 38.1 & 639 & 0 & 197 & 213 \\
\hline & Battery & & & & & & \\
\hline & Bus voltage $(\mathrm{V})$ & & & & & & \\
\hline & Energy in (kWh/year) & & & & & & \\
\hline & Energy out $(\mathrm{kWh} /$ year) & & & & & & \\
\hline 6 & Storage depletion $(\mathrm{kWh} /$ year) & & & & & & \\
\hline & Losses $(\mathrm{kWh} /$ year) & & & & & & \\
\hline & Annual throughput (kWh/year) & & & & & & \\
\hline & Expected life (Year) & & & & & & \\
\hline
\end{tabular}

\section{REFERENCES}

[1] Ramli, M. A., Hiendro, A., \& Twaha, S. (2015). Economic analysis of PV/diesel hybrid system with flywheel energy storage. Renewable Energy, 78, 398-405.

[2] Qudrat-Ullah, H., \& Kayal, A. A. (2019). Introduction: Climate Change and Energy Dynamics in the Middle East. In Climate Change and Energy Dynamics in the Middle East (pp. 3-13). Springer, Cham.

[3] Hearps, P., \& Cossar-Gilbert, S. (2019). Climate Change and Inequality: An Energy Revolution. Future, 21, 664.

[4] Goldthau, A., Westphal, K., Bazilian, M., \& Bradshaw, M. (2019). Model and manage the changing geopolitics of energy.

[5] Al-Mansour, F., Sucic, B., \& Pusnik, M. (2014). Challenges and prospects of electricity production from renewable energy sources in Slovenia. Energy, 77, 73-81.

[6] Kuramochi, T., Ramírez, A., Turkenburg, W., \& Faaij, A. (2013) Techno-economic prospects for $\mathrm{CO} 2$ capture from distributed energy systems. Renewable and Sustainable Energy Reviews, 19, 328-347.
[7] El Khashab, H., \& Al Ghamedi, M. (2015). Comparison between hybrid renewable energy systems in Saudi Arabia. Journal of Electrical Systems and Information Technology, 2(1), 111-119.

[8] Alawaji, S. H. (2001). Evaluation of solar energy research and its applications in Saudi Arabia-20 years of experience. Renewable and Sustainable Energy Reviews, 5(1), 59-77.

[9] Dorf, R. C. (1981). Energy factbook.[includes glossary].

[10] Alsharif, M. H. (2017). Optimization design and economic analysis of energy management strategy based on photovoltaic/energy storage for heterogeneous cellular networks using the HOMER model. Solar Energy, 147, 133-150.

[11] Aljarboua, Z. (2009). The national energy strategy for Saudi Arabia. World Academy of Science, Engineering and Technology, 57(3), 472 481 .

[12] Mahbub, A. M., Rehman, S., Meyer, J., \& Al-Hadhrami, L. M. (2011, November). Wind speed and power characteristics at different heights for a wind data collection tower in Saudi Arabia. In World Renewable Energy Congress-Sweden; 8-13 May; 2011; Linköping; Sweden (No. 057, pp. 4082-4089). Linköping University Electronic Press. 
[13] Al-Abbadi, N. M. (2005). Wind energy resource assessment for five locations in Saudi Arabia. Renewable Energy, 30(10), 1489-1499.

[14] Hepbasli, A., \& Alsuhaibani, Z. (2011). A key review on present status and future directions of solar energy studies and applications in Saudi Arabia. Renewable and sustainable energy reviews, 15(9), 5021-5050.

[15] Alawaji, S. H. (2001). Evaluation of solar energy research and its applications in Saudi Arabia-20 years of experience. Renewable and Sustainable Energy Reviews, 5(1), 59-77.

[16] Kaldellis, J. K., Kapsali, M., \& Kavadias, K. A. (2010). Energy balance analysis of wind-based pumped hydro storage systems in remote island electrical networks. Applied energy, 87(8), 2427-2437.

[17] Rezaie, B., Esmailzadeh, E., \& Dincer, I. (2011). Renewable energy options for buildings: case studies. Energy and Buildings, 43(1), 56-65.

[18] Santoso, S., \& Le, H. T. (2007). Fundamental time-domain wind turbine models for wind power studies. Renewable energy, 32(14), 2436-2452.

[19] Chen, W. H., Chen, C. Y., Huang, C. Y., \& Hwang, C. J. (2017). Power output analysis and optimization of two straight-bladed vertical-axis wind turbines. Applied energy, 185, 223-232.

[20] Himri, Y., Rehman, S., Draoui, B., \& Himri, S. (2008). Wind power potential assessment for three locations in Algeria. Renewable and Sustainable Energy Reviews, 12(9), 2495-2504.
[21] Himri, Y., Stambouli, A. B., \& Draoui, B. (2009). Prospects of wind farm development in Algeria. Desalination, 239(1-3), 130-138.

[22] Rehman, S., Halawani, T. O., \& Mohandes, M. (2003). Wind power cost assessment at twenty locations in the Kingdom of Saudi Arabia. Renewable Energy, 28(4), 573-583.

[23] Elshurafa, A. M., Alsubaie, A. M., Alabduljabbar, A. A., \& Al-Hsaien, S. A. (2019). Solar PV on mosque rooftops: Results from a pilot study in Saudi Arabia. Journal of Building Engineering, 25, 100809.

[24] Mustafa, A., Alghoul, M. A., Mohammed, M. N., Abulqasem, K., Glaisa, K., Amin, N., \& Sopian, K. (2014). Techno-Economic Analysis of Renewable Power System for a Remote Mosque in Libya. In Recent Advances in Energy, Environment and Development, Proceedings of the 9th International Conference on Energy \& Environment (EE'14) Geneva, Switzerland December (pp. 29-31).

[25] Rashid, E. E., Alwi, S. R. W., \& Manan, Z. A. (2011). Evaluation of photovoltaic system installation for a mosque in Universiti Teknologi Malaysia. PERINTIS eJournal, 1.

[26] Lunde, P. J. (1980). Solar thermal engineering: space heating and hot water systems. New York, John Wiley and Sons, Inc., 1980. 635 p.

[27] Al Garni, H. Z., Awasthi, A., \& Wright, D. (2019). Optimal orientation angles for maximizing energy yield for solar PV in Saudi Arabia. Renewable energy, 133, 538-550. 